ARAŞTIRMA / RESEARCH

\title{
Çocukluk çağı akut myeloid lösemilerinde lamin protein gen ekspresyonu
}

\author{
Lamin protein gene expression in childhood acute myeloid leukemias
}

Ayşe Özkan ${ }^{1}$, İbrahim Bayram ${ }^{1}$, Gülay Sezgin ${ }^{1}$, Can Acıpayam¹, Serhan Küpeli ${ }^{1}$, Atila Tanyeli ${ }^{1}$

${ }^{1}$ Çukurova Üniversitesi Tip Fakültesi, Pediatrik Onkoloji Bilim Dalı ve Pediatrik Kemik İliği Transplantasyon Ünitesi, Adana, Turkey

\begin{abstract}
Cukurova Medical Journal 2018;43 (Suppl 1):100-107
Abstract

Purpose: The aim of this study is to evaluate the prognostic value and expression pattern of lamin $\mathrm{A} / \mathrm{C}$, lamin B1 and B2 in childhood acute myeloid leukemias, which are thought to be related with cell proliferation and apoptosis.

Materials and Methods: Twenty-five patients diagnosed with acute myeloid leukemia (AML) and 35 control cases were included in the study. Real Time-Polymerase Chain Reaction (RT-PCR) method was used to detect lamin $\mathrm{A} / \mathrm{C}$, lamin $\mathrm{B} 1$ and lamin $\mathrm{B} 2$ protein gene expression at the time of the diagnosis and at the end of the induction treatment.

Results: At the time of the diagnosis, lamin B1 protein gene expression was lower in AML patients when compared to the control group. When lamin protein expression levels at the time of diagnosis and after induction therapy were compared, the lamin A/C and B2 protein gene expressions were lower after the administration of induction chemotherapy. AML patients with hepatomegaly when compared to patients without hepatomegaly, had only increased lamin A/C protein gene expression. Patients with splenomegaly had both increased lamin $\mathrm{A} / \mathrm{C}$ and lamin $\mathrm{B} 2$ protein gene expressions when compared to the patients without splenomegaly. Conclusion: In childhood acute myeloid leukemias, lamin B1 protein gene expression could be used as a diagnostic

Öz

Amaç: Bu çalışmanın amacı çocukluk çağı akut myeloid lösemilerinde (AML) hücre çoğalması ve apoptozis ile ilgili yollarla bağlantılı olduğu düşünülen lamin $\mathrm{A} / \mathrm{C}$, lamin $\mathrm{B} 1$ ve lamin B2 proteinlerinin gen ekspresyon durumunun saptanması ve prognoz ile olan ilişkilerinin değerlendirilmesidir.

Gereç ve Yöntem: AML tanısı alan 25 olgu ve 35 kontrol olgu çalışmaya alındı. Tanı anında ve indüksiyon tedavisi bitiminde lamin A/C, lamin B1 ve lamin B2 protein gen ekspresyonları Real Time-Polimeraz Zincir Reaksiyonu (RT-PCR) yöntemi ile çalışıldı.

Bulgular: AML hastalarında, tanı anında bakılan lamin B1 protein gen ekspresyonu kontrol grubuna göre belirgin olarak düşük bulundu. İndüksiyon tedavisi sonrası bakılan lamin A/C ve B2 protein gen ekspresyonu, tanı anına göre anlamlı olarak düşük saptandı. Lamin B1'de istatistiksel olarak anlamlı değişiklik saptanmadı. Hepatomegalisi olan AML hastalarında, hepatomegalisi olmayanlara göre lamin A/C, splenomegalisi olan AML hastalarında, splenomegalisi olmayanlara göre hem lamin A/C, hem de lamin B2 protein gen ekspresyonu artmış bulundu.

Sonuç: Çocukluk çağı akut myeloid lösemilerinde, lamin B1 protein gen ekspresyonu, tanısal bir belirteç olarak, indüksiyon tedavisi sonrasinda lamin A/C ve B2'nin azalması ise tedaviye alınan yanıtın bir göstergesi olarak kullanilabilir.
\end{abstract} marker, while decrease in the lamin $\mathrm{A} / \mathrm{C}$ and $\mathrm{B} 2$ protein gene expressions after induction could be used as a marker for response to therapy.

Key words: Acute myeloid leukemia, childhood, lamin proteins.
Anahtar kelimeler: Akut myeloid lösemi, çocukluk çağı, lamin proteinleri. 


\section{GİRİŞ}

Akut myeloid lösemi; miyeloid, monositik, eritroid ve megakaryositik hücre serilerinin kemik iliği prekürsörlerinin klonal proliferasyonu sonrasinda ortaya çıkan heterojen dağılımlı malign hastalık grubudur. Lösemik hücreler mitoz ile sınırsız bölünme ve çoğalma özelliği gösterirler ${ }^{1}$. Insan hücresindeki deoksiribo nükleik asit (DNA) materyali çekirdek denilen, zarfla çevrili bir organel içinde bulunmaktadır ${ }^{2}$. Nükleer lamina, çekirdek iç zar1 ile kromatin arasında yer alan yaklaşı $30-100$ nanometre kalınlığında fibröz ağ şeklinde bir yapıdır. Nükleer lamina, hücre çekirdeğinin iç zarı altında çekirdeğe mekanik destek sağlamanın yanı sıra, DNA replikasyonu ve hücre bölünmesi gibi önemli hücresel olayları da düzenler. Nükleer lamina, ara filamentlerden ve membran ilişkili proteinlerden oluşmaktadır.

Laminler, hücre zarının nükleoplasmik tarafinı kuşatan tip $\mathrm{V}$ ara filamentlerdir. İnsan somatik hücrelerinde lamin proteinlerini kodlayan 3 gen olduğu bilinmektedir. A tipi laminler (lamin A ve C), LMNA geninin ürünüdür. B tipi lamiler ise LMNB1 (lamin B1) ve LMNB2 (lamin B2) genleri tarafindan kodlanmıştır ${ }^{4-6}$. Lamin proteinleri, nükleer mimari, gen ekspresyonunun kontrolü, apoptozis, kromatin organizasyonu ve ayırımı gibi tümör progresyonunda yer alan hücresel olaylarda rol oynamaktadır? Laminler, genellikle, tümörde lokalize olan veya anormal eksprese edilen çok fonksiyonlu proteinlerdir ${ }^{8}$.

Laminlerin bir kanser belirteci olarak; kanserin tanisinin konulmasinda, özelliklerinin değerlendirilmesinde ve hastanın yaşam süresinin tahmin edilmesinde kullanımı ile ilgili çalışmalar vardır ${ }^{7}$. Lamin protein ekpresyonu ve kanser ilişkisi ile ilgili çalışmalar daha çok solid tümörlerde yapılmıştır ${ }^{8}$. Lösemilerde yapılmış çalışmalar çok azdır. $\mathrm{Bu}$ çalışmada, lamin protein gen ekspresyonunun çocukluk çağı akut myeloid lösemilerinde durumunun saptanmasını ve varsa prognoz ile ilişkisini araştırmayı amaçlanmıştır

\section{GEREÇ VE YÖNTEM}

Çukurova Üniversitesi Tip Fakültesi Çocuk Sağlığ1 ve Hastalıkları Anabilim Dalı, Pediatrik Onkoloji Bilim Dalına Ocak 2008 ile Mart 2014 tarihleri arasında başvuran ve akut myeloid lösemi tanısı alan ve tedavi edilen 29 hasta mevcut idi. Bu hastalardan yeterli ribo nükleik asiti (RNA'si) izole edilebilen 25'inde lamin protein gen ekspresyonları çalışılabilmiştir.

Çukurova Üniversitesi Tıp Fakültesi Çocuk Sağlığı ve Hastalıkları Anabilim Dalı, Genel Çocuk Polikliniğine kontrol amacıyla başvuran, fizik muayenesi normal saptanan ve tam kan sayımı ve periferik yayma ile hematolojik olarak normal bulunan 35 çocuk, kontrol grubu olarak çalışmaya dahil edildi. Çukurova Üniversitesi Tip Fakültesi Girişimsel Olmayan Klinik Araştırmalar Etik Kurulu'ndan, 11.10.2013 tarih ve 16 karar numarasıyla etik kurul onayı alındı. Hastaların ve kontrollerin yasal vasilerinden sözlü ve yazılı bilgilendirilmiş onam alındı.

\section{Uygulama}

Lösemi hastalarına tanısal amaçlı kemik iliği aspirayonu yapıldı ve morfolojik alt gruplar FrenchBritish-American (FAB) siniflamasina göre belirlendi. Aynı zamanda immünfenotiplendirme için akan hücre ölçer çalışması ile lenfosit yüzey antijenlerine yönelik monoklonal antikorlar ile yüzey belirteçlerine bakıldı. Bu işlem için hastalardan alınan 2 mililitre kemik iliği aspirasyon örneği, etilendiamin tetra asetik asit (EDTA) içeren tüplere alınıp, örnekler akan hücre ölçer (BD FACS Calibur) cihazından geçirilerek blastik hücre topluluğu içerisindeki hücrelerin yüzde oranları tespit edildi ve hücrelerin immünfenotiplendirmesi yapıldı. İmmünfenotiplendirme çalışmalarında CD (cluster of differentiation) yüzey belirteçlerinde \% 20'nin üzerinde olanlar pozitif olarak değerlendirildi.

Trombosit sayısının 150,000/ $\mathrm{mm}^{3}$ 'den düşük olması trombositopeni olarak ${ }^{9}$, lökosit sayısının o yaş grubuna göre -2 standart sapmadan (-2SD) daha düşük olması lökopeni olarak ve hemoglobin değerinin o yaş ve cinsiyet için -2SD'den daha düşük olması anemi olarak tanımland ${ }^{10}$.

Çalışmaya dahil edilen tüm olgulardan, tanı sırasında EDTA'lı tüpe alınan 3 mililitrelik kan örneğinden standart yöntemlerle hücre ayırma işlemi gerçekleştirildi. Hücrelerden RNA elde edildi. İzole edilen RNA örnekleri, çalışmanın yapılacağı güne kadar $-85^{\circ} \mathrm{C}$ 'de derin dondurucu içinde saklandi. Daha sonra bu RNA'lar komplementer deoksiribo nükleik asite (cDNA'ya) çevrilip $-20^{\circ}$ C'de muhafaza edildi. Hastaların ve kontrollerin periferik kan örneklerinde lamin A/C, B1, B2 proteinleri mRNA 
(haberci ribo nükleik asit) ekspresyonu RT-PCR yöntemi kullanılarak tespit edildi. Çalışma Light Cycler (Roche Applied Science) ile gerçekleştirildi.

Housekeeping Genler ve Target Genler dizayna uygun dalga boyunda LC 480 Software üzerinden "Advanced Relative Quantification" hesaplamalar1 ile analiz edildi.

\section{İstatistiksel analiz}

İstatiksel analizlerin tümü SPSS v22,0 (statical package for social sciences) paket programinda yapıldı. Olguların verilerinin değerlendirilmesinde korelasyon için
Pearson korelasyon testi, yaşam analizi için de, Kaplan-Meier testleri uygulandi. Ayrıca, grupların karşılaştırılmasında ANOVA testi (tek yönlü varyans analizi, one way) ve Mann Whitney $U$ testleri de kullanıldı. İstatistiksel olarak $\mathrm{p}<0.05$ anlamlı kabul edildi.

\section{BULGULAR}

Ocak 2008 ile Mart 2014 tarihleri arasında AML tanis1 alan ve yeterli RNA's1 izole edilebilen 25 olgunun FAB sinıflandırması Tablo 1'de verilmiştir. Kontrol say1s1 35'dir.

Tablo 1. FAB sınıflamasına göre AML hastalarının immünolojik sınıflandırması

\begin{tabular}{|l|c|c|}
\hline & $\mathbf{n}$ & $\mathbf{\%}$ \\
\hline AML-M0 & 2 & 8 \\
\hline AML-M1 & 3 & 12 \\
\hline AML-M2 & 1 & 4 \\
\hline AML-M3 & 0 & 0 \\
\hline AML-M4 & 10 & 40 \\
\hline AML-M5 & 3 & 12 \\
\hline AML-M6 & 1 & 4 \\
\hline AML-M7 & 2 & 8 \\
\hline AML Miks Lineage & 3 & 12 \\
\hline Toplam AML & 25 & 100 \\
\hline
\end{tabular}

Tablo 2. AML hastalarının tanı anı, tedavi sonrası ve kontrol grubunun lamin protein ekspresyon sonuçları

\begin{tabular}{|l|c|c|c|c|c|c|}
\hline $\begin{array}{l}\text { ort } \pm \text { SD } \\
\text { (aralik) [medyan] }\end{array}$ & $\begin{array}{c}\text { AML tan1 an1 } \\
\text { (n:25) }\end{array}$ & $\begin{array}{c}\text { AML tedavi } \\
\text { sonras1 (n:12) }\end{array}$ & $\begin{array}{c}\text { Kontrol grubu } \\
\text { (n:35) }\end{array}$ & Pa & $\mathbf{P}^{\mathbf{b}}$ & Pc \\
\hline Lamin A/C & $8.23 \pm 10.14$ & $0.35 \pm 0.26($ & $2.42 \pm 1.51$ & 0.0001 & 0.251 & 0.0001 \\
& $(0.12-40.50)$ & $0.11-1.00)$ & $(0.70-6.02)$ & & & \\
\hline Lamin B1 & {$[2.64]$} & {$[0.28]$} & {$[1.82]$} & & & 0.002 \\
& $1.74 \pm 1.10$ & $1.38 \pm 1.05$ & $3.28 \pm 2.30$ & 0.249 & 0.002 & \\
& $(0.33-4.59)$ & $(0.44-4.17)$ & $(0.00-9.78)$ & & & \\
\hline Lamin B2 & {$[1.51]$} & {$[1.1]$} & {$[2.46]$} & & & 0.0001 \\
& $(0.07 \pm 22.05$ & $1.65 \pm 2.32$ & $5.16 \pm 4.32$ & 0.007 & 0.887 & 0.007 \\
& {$[4.08]$} & $(0.33-8.40)$ & $(0.84-18.77)$ & & & \\
\hline
\end{tabular}

Pa:ilk tan1-indüksiyon tedavisi sonrası, Pb:ilk tan1-kontrol grubu, Pc:Kontrol grubu-indüksiyon tedavisi sonrası

AML hastalarının 16's1 erkek (\%64), 9'u k1z (\%36) olup, erkek/k1z oranı 1.78'dir. Kontrol grubunun 22'si erkek (\%62.9), 13’ü ( 37.1) kız olup erkek/k1z oranı 1.69'dur. AML hastalarının yaşı $122 \pm 54.4$ (12193) ve kontrol grubunun yaş1 $84.74 \pm 60.57$ (12-204) ay olup, kontrol grubu, cinsiyet ve yaş olarak AML hasta grubu ile benzerdi. AML hastalarının ortalama

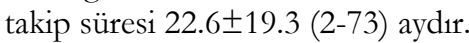

AML hastaları, idarubusin+ARA-C temelli tedavi protokolü ile tedavi edildiler ${ }^{11}$. 25 olgunun ilk remisyon indüksiyon kemoterapisi sonrasinda 23'ünde (\%92) remisyon sağlanmış, 2'sinde (\%8) remisyon sağlanamamıştır.

AML tanısı alan bir hastada tedaviye uyum kötü idi. AML M4 tanılı bu hastada sistemik relaps gelişmiş ve hasta takip ve tedaviye getirilmemiştir. AML M4 tanılı başka bir hasta sistemik relaps ve santral sinir sistemi relapsı gelişmesi sonucunda eksitus olmuştur. AML M0 tanilı bir hastada ise sistemik relaps gelişmiştir ve hastaya kök hücre nakli yapılmıştır, hasta sağ ve remisyondadır. AML indüksiyon kemoterapisi sonrasında 12 hastanın tekrar lamin 
proteinlerinin ekspresyonu çalıșılabilmiștir (Tablo 2). AML hastalarında, tanı anında bakılan lamin B1 protein gen ekspresyonu ortalama değeri 1.74 1 1.10; kontrol hastalarınin lamin B1 protein gen ekspresyonu ortalama değeri $3.28 \pm 2.30$ bulunmuş olup, aralarındaki bu fark istatistiksel olarak anlamlı bulunmuştur $\quad(p=0.002) \quad($ Tablo 2). AML hastalarında, tanı anında bakılan lamin $\mathrm{A} / \mathrm{C}$ protein gen ekspresyonu ortalama değeri kontrol grubuna göre yüksektir, ancak; istatistiksel olarak anlamlı değildir $(\mathrm{p}=0.251)$. İndüksiyon kemoterapisi sonras1 lamin $\mathrm{A} / \mathrm{C}$ ve $\mathrm{B} 2$ protein gen ekspresyon düzeyleri sirasiyla $0.35 \pm 0.26(0.11-1.00)$ ve $1.65 \pm 2.32(0.33$ 8.40) olup, bu değerler tanı anında ölçülen düzeylere göre (sirasiyla $8.23 \pm 10.14 \quad(0.12-40.50)$ ve $12.07 \pm 22.05$ (0.06-97.68)) anlamlı olarak düşüktür (sirasiyla $\mathrm{p}=0.0001$ ve 0.007 ).

Tablo 3. AML hastalarının özellikleri ile lamin protein gen ekspresyon sonuçlarının karşılaştırılması

\begin{tabular}{|c|c|c|c|c|}
\hline (ort $\pm S D)$ & $\mathrm{n}$ & $\begin{array}{c}\text { Tanı an1 } \\
\text { Lamin A/C }\end{array}$ & $\begin{array}{c}\text { Tan1 an1 } \\
\text { Lamin B1 }\end{array}$ & $\begin{array}{c}\text { Tan1 an1 } \\
\text { Lamin B2 }\end{array}$ \\
\hline \multicolumn{5}{|l|}{ Cinsiyet } \\
\hline $\mathrm{K}_{1 z}$ & 9 & $6.03 \pm 8.52$ & $1.57 \pm 1.29$ & $5.35 \pm 5.93$ \\
\hline Erkek & 16 & $9.46 \pm 11.0$ & $1.83 \pm 1.00$ & $15.84 \pm 26.7$ \\
\hline $\mathrm{P}$ & & 0.42 & 0.57 & 0.26 \\
\hline \multicolumn{5}{|l|}{ Lökopeni } \\
\hline Lökopeni var & 6 & $9.92 \pm 15.58$ & $1.45 \pm 0.37$ & $5.32 \pm 5.19$ \\
\hline Lökopeni yok & 19 & $7.69 \pm 8.27$ & $1.83 \pm 1.24$ & $14.20 \pm 24.9$ \\
\hline $\mathrm{P}$ & & 0.64 & 0.47 & 0.40 \\
\hline \multicolumn{5}{|l|}{ Trombositopeni } \\
\hline Trombositopeni var & 18 & $7.83 \pm 10.87$ & $1.99 \pm 1.11$ & $13.62 \pm 24.8$ \\
\hline Trombositopeni yok & 7 & $9.24 \pm 8.65$ & $1.09 \pm 0.79$ & $8.07 \pm 12.74$ \\
\hline $\mathrm{P}$ & & 0.76 & 0.065 & 0.58 \\
\hline \multicolumn{5}{|l|}{ Hepatomegali } \\
\hline Hepatomegali var & 11 & $13.24 \pm 12.7$ & $2.10 \pm 1.30$ & $20.85 \pm 31.2$ \\
\hline Hepatomegali yok & 14 & $4.29 \pm 5.25$ & $1.45 \pm 0.84$ & $5.16 \pm 5.56$ \\
\hline $\mathrm{P}$ & & 0.025 & 0.14 & 0.77 \\
\hline \multicolumn{5}{|l|}{ Splenomegali } \\
\hline Splenomegali var & 9 & $14.62 \pm 13.5$ & $2.22 \pm 1.41$ & $25.82 \pm 32.7$ \\
\hline Splenomegali yok & 16 & $4.63 \pm 5.30$ & $1.47 \pm 0.81$ & $4.33 \pm 5.44$ \\
\hline $\mathrm{P}$ & & 0.015 & 0.101 & 0.016 \\
\hline \multicolumn{5}{|l|}{ Lenfadenopati } \\
\hline Lenfadenopati var & 8 & $9.27 \pm 13.65$ & $1.56 \pm 1.12$ & $5.40 \pm 4.76$ \\
\hline Lenfadenopati yok & 17 & $7.74 \pm 8.47$ & $1.83 \pm 1.11$ & $15.20 \pm 26.2$ \\
\hline $\mathrm{P}$ & & 0.733 & 0.582 & 0.310 \\
\hline
\end{tabular}
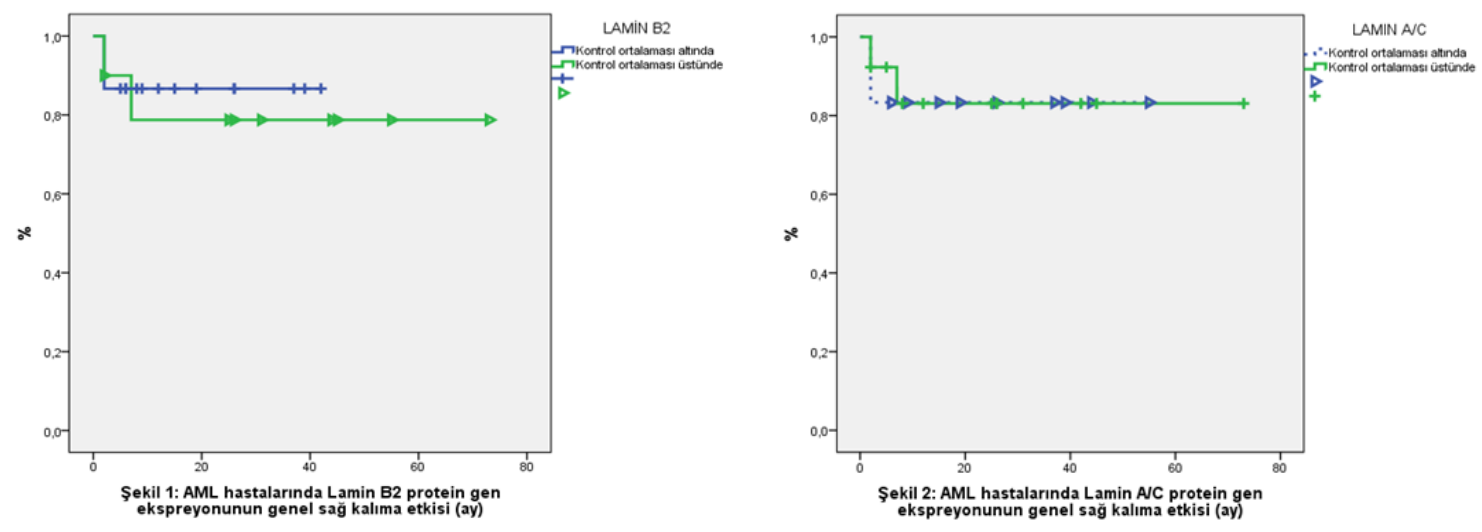
Lamin B1 düzeyleri ise tanı anında 1.74 $1.10(0.33$ 4.56) ölçülmüş olup indüksiyon kemoterapisi sonrasında $\quad 1.38 \pm 1.05 \quad(0.44-4.17) \quad$ olarak bulunmuştur ve iki ölçüm arasında istatistiksel olarak anlamlı fark bulunmamıştır $(p=0.249)$. Ayrıca, bu azalma kontrol grubunun ortalamasinin altina düşmekte olup, kontrol grubu ile karşılaştırıldığında istatistiksel olarak anlamlı bir azalma dikkati çekmektedir ( $\mathrm{p}=0.002)$ (Tablo 2).

Tanı anında lamin protein gen ekspresyon düzeyleri ile yaş, hematokrit, hemoglobin, beyaz küre, trombosit, üre, kreatinin, SGOT, laktik dehidrogenaz, ürik asit, alkalen fosfataz düzeyleri ve CD yüzey belirteçleri arasında Pearson korelasyon testi yapild1. Lamin A/C ve B1 protein gen ekspresyon düzeyleri ile bu parametreler arasinda istatistiksel olarak anlamlı olan bir korelasyon saptanmad. Lamin B2 protein gen ekspresyon düzeyi ile CD7 ve CD20 yüzey belirteçleri arasında pozitif korelasyon olduğu saptandı (sirasiyla $\mathrm{p}=0.001, \mathrm{r}=0.661$ ve $\mathrm{p}=0.001 \mathrm{r}=0.850)$.

AML hastalarının özellikleri ile lamin proteinlerinin gen ekspresyon sonuçlarının karşılaştırılması Tablo 3'de gösterilmiştir. Hepatomegalisi olan AML hastalarında lamin A/C protein gen ekspreyonu, hepatomegalisi olmayan AML hastalarına göre belirgin olarak yüksekti $(\mathrm{p}=0.025)$. Splenomegalisi olan hastalarda ise hem lamin $\mathrm{A} / \mathrm{C}$, hem de lamin B2 protein gen ekspresyonu, splenomegalisi olmayan hastalara göre belirgin olarak yüksekti (sırasiyla $\mathrm{p}=0.015$ ve $\mathrm{p}=0.016$ ). Indüksiyon tedavisi sonrasinda hastalar cinsiyete göre ve lökopeni, trombositopeni, hepatomegali, splenomegali, lenfadenopati olan ve olmayan diye gruplara ayrıldığında, ilgili gruplarda lamin protein gen ekspresyonlarına bakılan 6'dan az sayıda AML olgusu olduğu için istatistiksel değerlendirme yapılamamıştır.

Lamin A/C, B1, B2 proteinlerinin her birinin gen ekpresyonları, kontrol grubu ortalamasina göre düşük ve yüksek olmak üzere 2 gruba ayrıldı ve her birinin genel sağ kalıma etkisi araştırıldı. Lamin A/C proteini gen ekspresyonu kontrol ortalamasinin altında olan 12 olgu, kontrol ortalamasının üstünde olan 13 olgu vardi. Lamin B2 proteini için bu say1 sirasiyla 15 ve 12 olgu, lamin B1 proteini için sirasiyla 28 ve 2 olgudur (Lamin B1 protein ekspresyonunu değerlendirmek için, kontrol grubunun ortalamasindan yüksek olan hastaların sayısı istatistiksel değerlendirme yapabilmek için yeterli olmadığından (2 olgu) Kaplan-Meier genel sağ kalım analizi yapılamamıştır). AML hastalarında lamin B2 protein gen ekspresyonu, kontrol grubunun ortalamasından düşük olanların genel sağ kalım sonuçları daha iyiydi, ancak; sonuçlar istatistiksel olarak anlamlı değildi ( $\mathrm{p}>0.05)$. Lamin B2 protein gen ekspresyonu kontrol grubuna göre düşük olan AML hastalarında 3 ve 5 yıllık sağ kalım $\%$ 87, lamin B2 protein gen ekspresyonu düşük olan AML hastalarında 3 ve 5 yıllık sağ kalım \%80'dir (Şekil 1). AML hastalarında, kontrol grubunun ortalaması ile karşılaştırıldığında lamin A/C protein gen ekspresyonlarının genel sağ kalıma etkisi istatistiksel olarak anlamlı değildi (Şekil 2).

\section{TARTIŞMA}

Lösemi biyolojisinin anlaşılması, elde edilen bilgi birikimi ile yeni geliştirilen tedavi stratejileri, allojenik kök hücre nakli ve destekleyici tedaviler sonucunda ölümcül seyirli bu hastalık grubunun doğal seyri değiştirilebilmiştir. Son yayınlarda, gelişmiş ülkelerde özellikle AML için genel sağ kalım oranlarının \%6570’lerin üzerine çıkarılabildiği belirtilmiştir ${ }^{12}$. Çalışmamızdaki AML hastalarının 5 yıllık genel sağ kalım oranı $\% 80$ ile literatürle uyumlu idi.

Sitogenetik ve moleküler özelliklerin temelinde yapılacak olan prognostik faktörlerin belirlenmesi ile hastalı̆̆ın seyri öngörülebilir ve buna yönelik tedavisi planlanabilir. Özellikle yüksek risk grubundaki hastalara uygun ve doğru zamanda yapilacak allojenik kök hücre nakli ile hastalığın sağ kalım oranlarında artış sağlanabilir. Bazen iyi prognostik faktörlerin bulunduğu hastalarda da relaps görülebilmektedir ${ }^{13}$.

Lamin protein gen ekspresyonlarının baz1 kanserlerde anormal düzenlenmesi, bunların faydalı bir belirteç olarak kullanılmasını sağlamaktadır. Şu ana kadar yapılan çok sayıda çalışmada malign hücrelerde ve dokularda lamin proteinlerinin ekspresyonundaki farklılıklar incelenerek, laminler ile kanser alt tipleri arasındaki ilişki açıklanmaya çalışılmıştır ${ }^{14}$.

Çalışmamızda, AML hastalarında, tanı anında bakilan lamin B1 protein gen ekspresyonu, kontrol grubuna göre belirgin olarak düşük bulunmuştur. AML hastalarında, tanı anında bakilan lamin A/C ve lamin B2 protein gen ekspreyonu ise kontrol grubuna göre istatistiksel olarak farklı değildir. İndüksiyon tedavisi sonrası bakılan lamin B1 protein gen ekspresyon seviyeleri benzerken, lamin $\mathrm{A} / \mathrm{C}$ ve 
B2'de tedavi sonrasında tanı anına göre istatistiksel olarak anlamlı düşme görülmektedir.

Genel olarak A tipi laminlere 'statinler' denilmiş ve A tipi laminler hücre ve dokuların çoğalma göstermeyen ve farklılaşmamış durumu ile ilişkilendirilmiştir ${ }^{14}$ ancak, A tipi laminlerin, çok çeşitli kanser tiplerinde, kanserin alt tipi, agresifliği, çoğalma kapasitesi ve farklılaşma derecesine bağlı olarak farklı ekspresyon durumları sergileyebileceği de belirtilmiştir ${ }^{15}$. Skvortsov ve arkadaşları, lamin A'nın, prostat kanserlerinin derecelendirmesinde ve prognozunun belirlenmesinde yardımcı bir belirteç olduğunu bildirmişlerdir ${ }^{16}$. Buna ek olarak Willis ve arkadaşlarının yaptığı bir çalışmada, kolorektal kanser dokularında A tipi laminlerin, seviyesinin artışı, kanser ilişkili mortalitede iki kat artış ile ilişkili bulunmuştur ${ }^{17}$. Bizim çalışmamızda da AML hastalarımızda tanı anında, yani prolifere olan malign hücrelerin fazla olduğu dönemde lamin $\mathrm{A} / \mathrm{C}$ protein ekspresyonu yüksek iken, indüksiyon tedavisi sonrasinda, prolifere olan malign hücrelerin azalması ile lamin A/C protein ekspresyonunda anlaml derecede düşme saptanmıştır. Bu durumu tedaviye yanıt olarak da değerlendirilebiliriz.

Literatür incelendiğinde özefagus, serviks ve uterusun skuamöz ve adenokarsinomlarında, meme kanserleri ve bronşial karsinomlarda hem lamin B1 hem de lamin A/C ekspresyonları azalmış olarak saptanmıştır ${ }^{18}$. Sözü edilen kanserlerde, özellikle, lamin B1 ekspresyonunun azalmış olması, bizim çalışmamızla benzerdir. Hepatik ve pankreatik kanserlerde ise özellikle, lamin B1 ekspresyon paternleri farklıdır. Hepatoselüler karsinomlarda, lamin B1 ekspresyonunun artış1, tümörün boyutu, evresi ve nodül sayısı ile ilişkili bulunmuştur. Ayrıca, plasma lamin B1 seviyesinin artışının, hepatoselüler karsinomun erken evrede saptanmasında, bir belirteç olarak kullanılabileceği de gösterilmiștir ${ }^{19}$. Marshall ve arkadaşları ise yaptıkları bir çalışmada, lamin B1 ekspresyon artışının kolorektal kanserler için faydalı bir klinik belirteç olabileceğini göstermiştir ${ }^{20}$.

Li ve arkadaşları, pankreas kanserli hastalarda yaptığı bir çalışmada, lamin B1'in aşırı eksprese edilmesinin, bu hastalarda, düșük dereceli farklılaşma, uzak metastaz ve kötü prognoz ile direk ilişkili olduğunu bulmuştur. Betulinik asit tedavisi ile lamin B1 ekpresyonunun baskılanması sonucunda, pankreas kanserli hücrelerde proliferasyon, invazyon ve tümörojenik kapasitede azalma sağlanabilmiştir ${ }^{21}$.

Lamin A/C, lamin B1 ve lamin B reseptörü mRNA ekspresyonu 115 meme kanserli dokuda ve 30 kanserli olmayan meme dokusunda çalışılmışdır ve lamin A/C ekspresyonunun yüksek olmasının, erken klinik evre ve iyi prognoz ile ilişkili olduğu bulunmuștur. Lamin B1'in yüksek ekspresyonu kötü prognoz ile, lamin B reseptörünün yüksek ekspresyonu ise tümör derecesi ve Nottingham prognostik indeksi ile direk ilişkili bulunmuştur ${ }^{22}$.

Jansen ve arkadaşları, nodüler sklerozan Hodgkin lenfoma ve reaktif lenf nodlarındaki lamin protein ekspresyonlarını dokuda değerlendirmişlerdir. Lamin A pozitif hücrelerin proliferatif özellikte olmadığ1, özellikle lamin B2 ekspresyon düşüklügünün nodüler sklerozan Hodgkin lenfoma ile ilișkili olabileceği belirtilmiștir ${ }^{23}$. Aglero ve arkadașlarının yaptığı bir çalışmada ise lamin A/C geninin inaktive edilmesi ile diffüz büyük $\mathrm{B}$ hücreli lenfomalarda prognozun daha kötü olduğu gösterilmiştir ${ }^{24}$.

Kaufmann, lamin A/C'nin myeloid lösemilerde eksprese edildiğini göstermiştir. Lamin A/C ekpresyonunun tanı ve prognoz ile olan ilişkisini bulamamışdır ${ }^{25}$. Klymenko ve arkadaşları tarafindan, kronik lenfositik lösemili ve folliküler lenfomalı hastalarda yapılan bir çalışmada, lamin B1 ekspresyon seviyelerinin düșük olmasının hastaların olaysız yaşam ve genel sağ kalımlarıyla doğru orantılı olduğu gösterilmiştir ${ }^{26}$.

Çalışmamızda, AML hastalarının özellikleri ile lamin protein gen ekspresyonlar1 kontrol grubu ile karşılaştırıldığında, tanı anında hepatomegalisi olan hastalarda hepatomegalisi olmayanlara göre lamin A/C, splenomegalisi olanlarda splenomegalisi olmayanlara göre hem lamin A/C hem de lamin B2 protein gen ekspresyonu istatistiksel olarak anlamlı derecede artmış bulundu (Tablo 3).

Lamin A/C, B1, B2 proteinlerinin her birinin ekspresyonlar1, kontrol grubu ortalamasina göre düşük ve yüksek olmak üzere 2 gruba ayrıldı ve her birinin genel sağ kalıma etkisi araştırıldı. Lamin A/C, B1 ve B2 proteinlerinin gen ekspresyonlarının genel sağ kalım üzerine istatistiksel anlamlı bir etkisi olduğu gösterilemedi.

Sonuç olarak, çocukluk çağı AML hastalarında lamin proteinlerinin gen ekspresyonlarını değerlendirdiğimizde; tanı anında lamin $\mathrm{A} / \mathrm{C}$ ve B2 ortalama düzeyleri kontrol grubuna göre yüksek bulunmasına rağmen, istatistiksel bir farklilık saptanamadi. Bunun aksine, tanı anında lamin B1 protein gen ekspresyon düzeylerinde istatistiksel olarak anlamlı bir düşüklük saptandı. Ayrıca 
hepatomegali ve splenomegalisi olan hastalarda lamin A/C anlamlı olarak yüksek saptanırken, splenomegalisi olan hastalarda ek olarak lamin B2 düzeyinin de anlamlı olarak yüksek olduğu saptandı. Bu durum büyük ihtimalle tümör yükü ile ilisskiliydi. Indüksiyon tedavisi sonrasinda ise lamin $A / C$ ve B2'nin anlamlı olarak azaldığı görüldü. Tanı anına göre indüksiyon tedavisi sonrasinda, lamin $A / C$ 'nin ve B2'nin düşmesi, prolifere olan kanser hücrelerin azalmasıyla tedaviye alınan yanıtın bir göstergesi olarak yorumlanabilir.

Literatür incelendiğinde lamin protein ekspresyonları daha çok solid tümörlerde çalıșılmıștır. Hematolojik malignitelerde yapılan bir çalışma olan Kaufmann'ın çalışması erişkin myeloid lösemili hastalarda yapılmış, ancak, sadece lamin A/C'nin eksprese olduğu gösterilmiş ve bu durumun tanı ve prognoz ile olan ilişkisi gösterilememiştir ${ }^{25}$. Klymenko ve arkadaşları tarafından yapılan çalışma ise yine erişkin kronik lenfositik lösemili ve folliküler lenfomalı hastalarda yapılmış ve düşük lamin B1 ekspresyon seviyelerinin hastaların olaysız yaşam ve genel sağ kalımlarıyla doğru orantılı olduğu gösterilmiştir ${ }^{26}$.

Sonuç olarak, çocukluk çağı akut myeloid lösemilerinde lamin B1 protein gen ekspresyonunun düşük olması tanısal bir belirteç olarak, indüksiyon tedavisi sonrasında lamin A/C ve B2'nin anlamlı olarak azalması ise tedaviye alınan yanıtın bir göstergesi olarak kullanılabilir. Çalışmamız, çocukluk çağında akut myeloid lösemilerinde lamin proteinlerinin tanı ve prognoz ile ilişkisine yönelik yapılan literatürdeki ilk çalışma olup, daha kapsamlı, birden fazla merkezin yapacağı çok vakalı çalıșmalar ile bu sonuçların daha da netleșeceğini ve lamin proteinlerinin tanı ve prognoz ile olan ilişkisinin ortaya çıkarılacağını düşünmekteyiz.

\section{TEŞEKKÜR}

Bu araştırma Çukurova Üniversitesi Rektörlüğü'nün Bilimsel Araştırma Projeleri komisyonunun (BAP) TF2013LTP34 (ID715) nolu proje desteği ile yapılmıştır.

\section{KAYNAKLAR}

1. Arceci RJ, Meshinchi S. Acute Myeloid Leukemia and Myelodysplastic Syndromes. In: Pizzo PA and Poplack DG, Eds. Principles and Practice of Pediatric Oncology, 7th ed. Philadelphia: Wolters Kluwer. 2016:498-544.
2. Lodish H, Berk A, Kaiser CA, Krieger M, Scott MP, Bretscher A et al. Yaşam Hücrelerle Başlar. (Ceviri Eds Geçkil H, Özmen M, Yeşilada Ö.) Moleküler Hücre Biyolojisi. 6. Baskıdan çeviri. Ankara, Palme Yayıncilik. 2011:1-30.

3. Goldman RD, Goldman AE, Shumaker DK. Nuclear lamins: building blocks of nuclear structure and function. Novartis Found Sym. 2005;264:3-16.

4. Lin F, Worman HJ. Structural organization of the human gene encoding nuclear lamin A and nuclear lamin C. J Biol Chem. 1993;268:16321-6.

5. Machiels BM, Zorenc AH, Endert JM, Kuijpers HJ, Van GJ, Ramaekers FC et al. An alternative splicing product of the lamin A/C gene lacks exon 10. J Biol Chem. 1996;271:9249-53.

6. Lin F, Worman HJ. Structural organization of the humangene (LMNB1) encoding nuclear lamin B1. Genomics, 1995;27:230-6.

7. Foster CR, Przyborski SA, Wilson RG, Hutchison CJ. Lamins as cancer biomarkers. Biochem Soc Trans. 2010;38:297-300.

8. Dittmer T, Mitseli T. The lamin protein family. Genome Biology. 2011;12:222.

9. Cheng CK, Chan J, Cembrowsky GS, Van Assendelft OW. Complete blood count reference interval diagrams derived from NHANES III: startification by age, sex and race. Lab Hematol. 2004;10:42-53.

10. Lanzkowsky P (ed.). Manuel of Pediatric Hematology and Oncology. 6th ed. New York, Churchill Livingstone Inc. 2016;709-28.

11. Bayram I, Erbey F, Kömür M, Tanyeli A. Total parenteral nutrition and decreased dose idarubicin based treatment of acute myeloid leukemia during childhood. Eur J Gen Med. 2010;7:282-7.

12. Gamis AS, Alonzo TA, Perentesis JP, Meshinchi S. Children's Oncology Group's 2013 blueprint for research acute myeloid leukemia. Pediatr Blood Cancer. 2013;60:964.

13. McKenney AH, Cleary ML, Arber DA. Pathology and Molecular Diagnosis of Leukemias and Lymphomas. In: Pizzo PA, Poplack DG, Eds. Principles and Practice of Pediatric Oncology, 7th ed. Philadelphia: Wolters Kluwer. 2016:113-30.

14. Broers JL, Ramaekers FC. The role of the nuclear lamina in cancer and apoptosis. Adv Exp Med Biol. 2014;773:27-48.

15. Tilli CM, Ramaekers FC, Broers JL, Hutchison CJ, Neumann HA. Lamin expression in normal human skin, actinic keratosis, squamous cell carcinoma and basal cell carcinoma. Br J Dermatol. 2003;148:102-9.

16. Skvortsov S, Schafer G, Stasyk T, Fuchsberger C, Bonn GK, Bartsch $G$ et al. Proteomics profiling of microdissected low- and high-grade prostate tumors identifies lamin a as a discriminatory biomarker. J Proteome Res. 2011;10:259-68.

17. Willis ND, Cox TR, Rahman-Casans SF, Smits K, Przyborski SA, van den Brandt P et al. Lamin A/C is 
a risk biomarker in colorectal cancer. PLoS One. 2008;3:2988

18. Sakthivel M, Sehgal P. A novel role of lamins from genetic disease to cancer biomarkers. Oncology reviews. 2016;10:309

19. Sun $\mathrm{S}, \mathrm{Xu} \mathrm{MZ}$, Poon RT, Day PJ, Luk JM. Circulating Lamin B1 (LMNB1) biomarker detects early stages of liver cancer in patients. J Proteome Res. 2010;9:70-8.

20. Marshall KW, Mohr S, Khettabi FE, Nossova N, Chao S, Bao W et al. A blood-based biomarker panel for stratifying current risk for colorectal cancer. Int J Cancer. 2010;126:1177-86.

21. Li L, Du Y, Kong X, Li Z, Cui J et al. Lamin B1 is novel therapeutic target of betulinic acid in pancreatic cancer. Clin Cancer Res. 2013;19:4651-61.

22. 22. Wazir U, Ahmed MH, Bridger JM, Harvey A, Jiang WG, Sharma AK et al. The clinicopathological significance of lamin A/C, lamin B1 and lamin B receptor mRNA expression in human breast cancer.
Cell Mol Biol Let. 2013;18:595-611.

23. Jansen MP, Machiels BM, Hopman AH, Broers JL, Bot FJ, Arends JW et al. Comparison of A and Btype lamin expression in reactive lymph nodes and nodular sclerosing Hodgkin's disease. Histopathology. 1997;31:304-312.

24. Aglero R, Setien F, Espada J, Artiga MJ, Rodriguez $\mathrm{M}$, Perez-Rosado A et al. Inactivation of the lamin $\mathrm{A} / \mathrm{C}$ gene by $\mathrm{CpG}$ island promoter hypermethylation in hematologic malignancies, and its association with poor survival in nodal diffuse large B-cell lymphoma. J Clin Oncol. 2005;23:3940-7.

25. Kaufmann SH. Expression of Nuclear Envelope Lamins A and C in Human Myeloid Leukemias. Cancer Research. 1992;52:2847-53.

26. 26. Klymenko T, Bloehdorn J, Bahlo J, Robrecht $\mathrm{S}$, Akylzhanova G, Cox $\mathrm{K}$ et al. Lamin B1 regulates somatic mutations and progression of B-cell malignancies. Leukemia. 2018;32:364-75. 